\title{
Kelayakan Upah Minimum Provinsi (UMP) Daerah Istimewa Yogyakarta Dalam Memenuhi Kebutuhan Hidup Layak Pekerja Tahun 2019
}

\author{
Yoko Prasetiyo ${ }^{1}$, Ane Permatasari ${ }^{2}$ \\ ${ }^{1}$ program studi Ilmu Pemerintahan, Fakultas Ilmu Sosial dan Ilmu Politik, niversitas Muhammadiyah \\ Yogyakarta Jalan Brawijaya, Tamantirto,Kasihan, Bantul, Yogyakarta 55183 \\ ${ }^{2}$ program studi Ilmu Pemerintahan, Fakultas Ilmu Sosial dan Ilmu Politik, niversitas Muhammadiyah \\ Yogyakarta Jalan Brawijaya, Tamantirto,Kasihan, Bantul, Yogyakarta 55183 \\ Email korespondensi: yoko_famous01@gmail.com
}

\begin{abstract}
This research was conducted with the aim to find out the Provincial Minimum Wage (UMP) of the Special Region of Yogyakarta in Meeting the Needs of a Decent Life for Workers in 2019. The study used primary data obtained based on interviews with authorized officials at the DIY Manpower and Transmigration Office as well as secondary data as data to strengthen research analysis. The data were processed and analyzed using qualitative analysis techniques. The results of this study indicate that the feasibility variable in determining the amount of wages and assistance for workers / laborers to fight for their rights in fulfilling the wages that must be received, fighting for workers / laborers' rights in the process of achieving welfare in wages is a form of justice to continue to achieve welfare for workers. workers in the Special Region of Yogyakarta.
\end{abstract}

Keywords: Decent life, Welfare, Justice

Abstrak: Pelatihan dilakukan dengan tujuan untuk mengetahui Kelayakan Upah Minimum Provinsi (UMP) Daerah Istimewa Yogyakarta Dalam Memenuhi Kebutuhan Hidup Layak Pekerja Tahun 2019. Penelitian menggunakan data primer yang diperoleh berdasarkan wawancara terhadap pejabat yang berwenang pada Disnakertrans DIY serta data sekunder sebagai data untuk memperkuat analisa penelitian. Data diolah dan dianalisis dengan menggunakan teknik analisis kualitatif. Hasil penelitian ini menunjukkan bahwa variabel kelayakan dalam menentukan besaran upah dan pendampingan bagi pekerja/buruh untuk memperjuangkan haknya dalam terpenuhinnya upah yang harus diterima, memperjuangkan hak pekerja /buruh dalam proses untuk mencapai kesejahteraan dalam pengupahan adalah bentuk keadilan untuk terus mencapai kesejahteraan bagi para pekerja/buruh di Daerah Istimewa Yogyakarta.

Kata kunci : Kelayakan Hidup layak, Kesejahteraan, Keadilan.

Article History:

Received : 2020-11-1

Revised : 2020-11-14

Accepted : 2020-12-24

\section{PENDAHULUAN}

Setiap individu pasti memiliki tujuan yang ingin dicapai. Umumnya tujuan hidupnya adalah mencapai kebahagiaan dan kesuksesan, namun untuk mencapainya setiap individu memiliki cara yang berbeda. Kestabilan ekonomi keluarga merupakan faktor yang dapat mengukur kebahagiaan di dalam keluarga, yaitu keluarga dapat memenuhi kebutuhan hidupnya, baik kebutuhan sekarang maupun kebutuhan masa depan serta mencapai tujuan hidupnya (T.Istrilista, 2016). Saat ini, banyak sekali keluarga yang mengalami kesulitan dan sering mengeluh akibat pendapatan yang di terima kurang cukup untuk memenuhi kebutuhan hidupnya, karena biaya-biaya untuk memenuhi kebutuhan keluarga sehari-hari semakin meningkat. Kerja merupakan salah satu kegiatan penting bagi kehidupan manusia, bahkan terkadang menjadi sangat dominan dibanding dengan aktifitas- aktifitas lainnya terutama dalam pemenuhan kebutuhan hidup.

Antara pekerja/buruh dan pengusaha mempunyai persamaan kepentingan adalah kelangsungan hidup dan kemajuan perusahaan, tetapi di sisi lain hubungan antar keduanya juga memiliki perbedaan dan bahkan potensi konflik, terutama yang apabila berkaitan dengan persepsi atau interpretasi yang tidak sama tentang kepentingan masing-masing pihak yang pada dasarnya memang ada perbedaan. Upah harus diberikan secara adil dan tidak merugikan salah 
satu pihak. Adil secara bahasa mengandung dua arti, tidak berat sebelah (tidak memihak) dan sepatutnya, tidak sewenang-wenang. Upah adalah hak pekerja/buruh yang diterima dan dinyatakan dalam bentuk uang sebagai imbalan dari pengusaha atau pemberi kerja kepada pekerja/buruh yang ditetapkan dan dibayarkan menurut suatu perjanjian kerja, kesepakatan, atau peraturan perundang-undangan, termasuk tunjangan bagi pekerja/buruh dan keluarganya atas suatu pekerjaan atau jasa yang telah dilakukan (UU Nomor 13 Tahun 2003 tentang Ketenagakerjaan).

Berbicara mengenai Kelayakan Hidup Layak bagi para pekerja/buruh selalu erat kaitannya dengan upah yang diperoleh bagi pekerja/buruh. Upah hanya dijadikan salah satu instrumen dalam upaya peningkatan kesejahteraan tenaga kerja sehingga berbagai kebijakan selalu dibenturkan pada peningkatan upah minimum yang menjadi beban bagi para pelaku usaha. Hal ini menunjukkan bahwa peningkatan kesejahteraan pekerja sepenuhnya merupakan tanggung jawab pengusaha atau pemberi kerja. Padahal pemerintah daerah adalah salah satu wakil negara dalam mewujudkan kesejahteraan warga negara secara umum. Dalam hal ini pelaku usaha juga diharapkan untuk selalu sejalan dengan memperhatikan kinerja para pekerja dengan hasil pekerjaan di bidang usahanya dan diharapkan terus memperhatikan Kelayakan Hidup Layak bagi para pekerja dan selalu memperhatikan kesejahteraan pekerja dengan cara memakmurkannya dari segi pengupahan, di luar dari masalah kesejahteraan dalam pengupahan bagi buruh/pekerja, pemerintah daerah dituntut untuk membangun, menciptakan, dan meningkatkan kapasitas tenaga kerja. Artinya bahwa peran pemerintah daerah dalam melakukan pembangunan tenaga kerja harus berjalan lurus dan selalu berhubungan dengan kesejahteraan pekerja.

Tabel .1 Kebutuhan Hidup Layak (KHL)

\begin{tabular}{|c|c|c|c|}
\hline No & Komponen & Kualitas/Kriteria & Jumlah Kebutuhan \\
\hline I & MAKANAN DAN MINUMAN & & \\
\hline 1 & Beras Sedang & Sedang & $10 \mathrm{~kg}$ \\
\hline \multirow[t]{4}{*}{2} & Sumber Protein : & & \\
\hline & a. Daging & Sedang & $0.75 \mathrm{~kg}$ \\
\hline & b. Ikan Segar & Baik & $1.2 \mathrm{~kg}$ \\
\hline & c. Telur Ayam & Telur ayam ras & $1 \mathrm{~kg}$ \\
\hline 3 & Kacang-kacangan : tempe/tahu & Baik & $4.5 \mathrm{~kg}$ \\
\hline 4 & Susu bubuk & Sedang & $0.9 \mathrm{~kg}$ \\
\hline 5 & Gula pasir & Sedang & $3 \mathrm{~kg}$ \\
\hline 6 & Minyak goreng & Curah & $2 \mathrm{~kg}$ \\
\hline 7 & Sayuran & Baik & $7.2 \mathrm{~kg}$ \\
\hline 8 & $\begin{array}{l}\text { Buah-buahan } \\
\text { pisang/pepaya) }\end{array}$ & Baik & $7.5 \mathrm{~kg}$ \\
\hline 9 & $\begin{array}{l}\text { Karbohidrat lain (setara tepung } \\
\text { terigu) }\end{array}$ & Sedang & $3 \mathrm{~kg}$ \\
\hline 10 & Teh atau Kopi & Celup/Sachet & 2 Dus isi $25=75 \mathrm{gr}$ \\
\hline \multirow[t]{2}{*}{11} & Bumbu-bumbuan & Nilai $1 \mathrm{~s} / \mathrm{d} 10$ & $15 \%$ \\
\hline & JUMLAH & & \\
\hline II & SANDANG & & \\
\hline 12 & $\begin{array}{l}\text { Celana panjang/ Rok/Pakaian } \\
\text { muslim }\end{array}$ & Katun/sedang & $6 / 12$ potong \\
\hline 13 & Celana pendek & Katun/sedang & $2 / 12$ potong \\
\hline 14 & Ikat Pinggang & $\begin{array}{l}\text { Kulit sintetis, polos, tidak } \\
\text { branded }\end{array}$ & $1 / 12$ buah \\
\hline 15 & Kemeja lengan pendek/blouse & Setara katun & $6 / 12$ potong \\
\hline 16 & Kaos oblong/ BH & Sedang & $6 / 12$ potong \\
\hline
\end{tabular}




\begin{tabular}{|c|c|c|c|}
\hline No & Komponen & Kualitas/Kriteria & Jumlah Kebutuhan \\
\hline 17 & Celana dalam & Sedang & $6 / 12$ potong \\
\hline 18 & Sarung/kain panjang & Sedang & $1 / 12$ helai \\
\hline 19 & Sepatu & Kulit sintetis & 2/12 pasang \\
\hline 20 & Kaos Kaki & $\begin{array}{l}\text { Katun, Polyester, Polos, } \\
\text { Sedang }\end{array}$ & 4/12 pasang \\
\hline \multirow[t]{3}{*}{21} & Perlengkapan pembersih sepatu & & \\
\hline & a. Semir sepatu & Sedang & $6 / 12$ buah \\
\hline & b. Sikat sepatu & Sedang & $1 / 12$ buah \\
\hline 22 & Sandal jepit & Karet & $2 / 12$ pasang \\
\hline 23 & Handuk mandi & $100 \mathrm{~cm} \times 60 \mathrm{~cm}$ & $2 / 12$ potong \\
\hline \multirow[t]{5}{*}{24} & Perlengkapan ibadah & & \\
\hline & a. Sajadah & Sedang & $1 / 12$ potong \\
\hline & b. Mukena & Sedang & 1/12 potong \\
\hline & c. Peci,dll & Sedang & 1/12 potong \\
\hline & JUMLAH & & \\
\hline III & PERUMAHAN & & \\
\hline 25 & Sewa kamar & $\begin{array}{l}\text { dapat menampung jenis KHL } \\
\text { lainnya }\end{array}$ & 1 bulan \\
\hline 26 & Dipan/ tempat tidur & No.3, polos & $1 / 48$ buah \\
\hline \multirow[t]{3}{*}{27} & Perlengkapan tidur & & \\
\hline & a. Kasur busa & Busa & $1 / 48$ buah \\
\hline & b. Bantal busa & Busa & $2 / 36$ buah \\
\hline 28 & Sprei dan sarung bantal & Katun & $2 / 12$ set \\
\hline 29 & Meja dan kursi & $1 \mathrm{meja} / 4$ kursi & $1 / 48$ set \\
\hline 30 & Lemari pakaian & Kayu sedang & $1 / 48$ buah \\
\hline 31 & Sapu & Ijuk sedang & $2 / 12$ buah \\
\hline \multirow[t]{4}{*}{32} & Perlengkapan makan & & \\
\hline & a. Piring makan & Polos & $3 / 12$ buah \\
\hline & b. Gelas minum & Polos & $3 / 12$ buah \\
\hline & c. Sendok garpu & Sedang & $3 / 12$ pasang \\
\hline 33 & Ceret aluminium & Ukuran $25 \mathrm{~cm}$ & $1 / 24$ buah \\
\hline 34 & Wajan aluminium & Ukuran $32 \mathrm{~cm}$ & $1 / 24$ buah \\
\hline 35 & Panci aluminium & Ukuran $32 \mathrm{~cm}$ & $2 / 12$ buah \\
\hline 36 & Sendok masak & Alumunium & $1 / 12$ buah \\
\hline 37 & Rice Cooker ukuran $1 / 2$ liter & 350 watt & $1 / 48$ buah \\
\hline \multirow[t]{4}{*}{38} & Kompor dan perlengkapannya & & \\
\hline & a. Kompor 1 tungku & SNI & $1 / 24$ buah \\
\hline & b. Selang dan regulator & SNI & 10 liter \\
\hline & c. Tabung Gas $3 \mathrm{~kg}$ & Pertamina & $1 / 60$ buah \\
\hline 39 & Gas Elpiji & masing-masing $3 \mathrm{~kg}$ & 2 tabung \\
\hline 40 & Ember plastik & Isi 20 liter & $2 / 12$ buah \\
\hline 41 & Gayung plastik & Sedang & $1 / 12$ buah \\
\hline 42 & Listrik & 900 watt & 1 bulan \\
\hline 43 & Bola lampu hemat energi & 14 watt & $3 / 12$ buah \\
\hline 44 & Air Bersih & Standar PAM & 2 meter kubik \\
\hline 45 & Sabun cuci pakaian & Cream/deterjen & $1.5 \mathrm{~kg}$ \\
\hline 46 & Sabun cuci piring (colek) & $500 \mathrm{gr}$ & 1 buah \\
\hline 47 & Setrika & 250 watt & $1 / 48$ buah \\
\hline 48 & Rak portable plastik & Sedang & $1 / 24$ buah \\
\hline 49 & Pisau dapur & Sedang & $1 / 36$ buah \\
\hline 50 & Cermin & $30 \times 50 \mathrm{~cm}$ & $1 / 36$ buah \\
\hline
\end{tabular}




\begin{tabular}{|c|c|c|c|}
\hline No & Komponen & Kualitas/Kriteria & Jumlah Kebutuhan \\
\hline & JUMLAH & & \\
\hline IV & PENDIDIKAN & & \\
\hline 51 & Bacaan/radio & Tabloid/4 band & 4 buah/ (1/48) \\
\hline \multirow[t]{2}{*}{52} & Ballpoint/pencil & Sedang & $6 / 12$ buah \\
\hline & JUMLAH & & \\
\hline $\mathrm{V}$ & KESEHATAN & & \\
\hline \multirow[t]{6}{*}{53} & Sarana Kesehatan & & \\
\hline & a. Pasta gigi & 80 gram & 1 tube \\
\hline & b. Sabun mandi & 80 gram & 2 buah \\
\hline & c. Sikat gigi & Produk lokal & $3 / 12$ buah \\
\hline & d. Shampo & Produk lokal & 1 botol $100 \mathrm{ml}$ \\
\hline & e. Pembalut atau alat cukur & Isi 10 & $1 \mathrm{dus} / \mathrm{set}$ \\
\hline 54 & Deodorant & $100 \mathrm{ml} / \mathrm{g}$ & $6 / 12$ botol \\
\hline 55 & Obat anti nyamuk & Bakar & 3 dus \\
\hline 56 & Potong rambut & Di tukang cukur/salon & $6 / 12$ kali \\
\hline \multirow[t]{2}{*}{57} & Sisir & Biasa & $2 / 12$ buah \\
\hline & JUMLAH & & \\
\hline VI & TRANSPORTASI & & \\
\hline \multirow[t]{2}{*}{58} & Transportasi kerja dan lainnya & Angkutan umum & 30 hari $(\mathrm{PP})$ \\
\hline & JUMLAH & & \\
\hline VII & REKREASI DAN TABUNGAN & & \\
\hline 59 & Rekreasi & Daerah sekitar & $2 / 12$ kali \\
\hline 60 & Tabungan & (2\% dari nilai $1 \mathrm{~s} / \mathrm{d} 59)$ & $2 \%$ \\
\hline
\end{tabular}

Sumber : Peraturan Menteri ketenagakerjaan No 21 tahun 2016 tentang Kebutuhan Hidup layak.

Berdasarkan tabel diatas terdapat 60 Komponen Hidup layak Jumlah rupiah dari semua jenis kebutuhan di atas merupakan nilai KHL. Namun, seperti diketahui bahwa sejak 2015 pemerintah tidak lagi meninjau dan menetapkan komponen KHL dan jenis kebutuhan setiap tahun, tetapi setiap 5 tahun sekali sesuai PP Pengupahan No 78/2015, Pasal 43 ayat (5) sampai dengan (8):

1. Komponen sebagaimana dimaksud pada ayat (3) dan jenis kebutuhan hidup sebagaimana dimaksud pada ayat (4) ditinjau dalam jangka waktu 5 tahun.

2. Peninjauan komponen dan jenis kebutuhan hidup sebagaimana dimaksud pada ayat (5) dilakukan oleh Menteri dengan mempertimbangkan hasil kajian yang dilaksanakan oleh Dewan Pengupahan Nasional.

3. Kajian yang dilaksanakan oleh Dewan Pengupahan Nasional sebagaimana dimaksud pada ayat (6) menggunakan data dan informasi yang bersumber dari lembaga yang berwenang di bidang statistik.

4. Hasil peninjauan komponen dan jenis kebutuhan hidup sebagaimana dimaksud pada ayat (6) menjadi dasar perhitungan upah minimum selanjutnya dengan memperhatikan produktivitas dan pertumbuhan ekonomi. 
Tabel .2 besaran Upah Minimum Kabupaten/Kota tahun 2018

\begin{tabular}{|c|c|c|}
\hline No & Kabupaten/Kota & Upah Minimum Kabupaten/ Kota \\
\hline 1 & Kota Yogyakarta & Rp. $1.709 .150,00$ \\
\hline 2 & Kabupaten Sleman & Rp. $1.5 .74 .550,00$ \\
\hline 3 & Kabupaten Bantul & RP. $1.527 .550,00$ \\
\hline 4 & Kabupaten Kulon Progo & RP. $1.493 .250,00$ \\
\hline 5 & Kabupaten Gunung Kidul & Rp. 1.454 .200 .00 \\
\hline
\end{tabular}

Sumber : Keputusan Gubernur DIY tentang penetapan Upah Minimum Kabupaten/kota tahun 2018

Tabel .3 Besaran Upah Minimum Kabupaten/ kota tahun 2019

\begin{tabular}{ccc}
\hline No & Kabupaten/Kota & Upah Minimum Kabupaten/Kota \\
\hline 1 & Kota Yogyakarta & Rp. 1.846 .400 .00 \\
\hline 2 & Kabupaten Sleman & Rp. 1.701 .000 .00 \\
\hline 3 & Kabupaten Bantul & Rp. 1.649 .800 .00 \\
\hline 4 & Kabupaten Kulon progo & Rp. 1.613 .200 .00 \\
\hline & Kabupaten Gunung Kidul & Rp. 1.571 .000 .00 \\
\hline & Sumber : Keputusan Gubernur DIY tentang penetapan Upah Minimum Kabupaten/Kota tahun 2019
\end{tabular}

Berdasarkan tabel 1.2 dan 1.3 diatas dapat dilihat bahwa pada kenyataannya upah yang diterima oleh tenaga kerja lebih rendah bila dibandingkan dengan Kebutuhan Hidup Layak. Pada tahun 2019 tingkat Kebutuhan Hidup Layak Provinsi DIY mencapai Rp. 1.846.400.00 diperkirakan meningkat sebesar Rp. 137.250.00 dibanding tahun sebelumnya (2018) sebesar Rp. 1.709.150.00. perbandingan antara Kebutuhan Hidup Layak dan Upah Minimum Provinsi tidak sebanding dengan harapan masyarakat. Namun pada Tahun 2018 hingga 2019 Kebutuhan Hidup Layak Provinsi DIY mengalami peningkatan dikarenakan kenaikan harga akan berakibat pada kenaikan Kebutuhan Hidup Layak dan selanjutnya akan meningkatkan upah minimum.

Dalam rangka menentukan upah, Kartaspura menjelaskan tentang sifat dan karakteristik upah yang fundamental yaitu upah harus dapat menjamin upah minimum, sehingga para pekerja tidak kekurangan konsentrasi karena banyak mengingat kebutuhan- kebutuhannya yang belum terpenuhi (Kartasapura, 1992: 102). Pengawasan dalam pelaksanaan Upah Minimum Provinsi adalah upaya kegiatan untuk selalu menjamin agar setiap pengusaha dan perusahaan-perusahaan yang terdapat di Provinsi DIY dalam memberikan upah layak kepada pekerja/buruh supaya tidak menyimpang dari UMP yang telah ditetapkan oleh Gubernur Daerah Istimewa Yogyakarta, dalam pengawasannya yang dilakukan oleh Dinas Tenaga Kerja provinsi DIY dalam mewujudkan kebijakan upah minimum berdasarkan adanya penetapan upah minimum provinsi, kebijakan yang sudah disahkan oleh Gubernur DIY kemudian diterapkan disemua perusahaan yang terdapat di provinsi DIY. Tujuan pengawasan agar pelaksanaan dalam menjalankan tugas-tugas umum dan pengembangan pembangunan oleh instansi yang bersangkutan supaya berjalan sesuai dengan rencana dan kebijaksanaan pemerintah sehingga dapat terwujud sesuai dengan sasaran yang di tetapkan sesuai dengan fungsinya, dalam fungsi pengawasan sebagai salah satu bentuk untuk mencegah terjadinya kebocoran dan pemborosan serta memperlancar pelaksanaan program dan yang sudah di terapkan dan di tetapkan.

Pengawasan ini sungguh sangat diperlukan dan tetap harus dilaksanakan oleh Dinas Tenaga Kerja Provinsi DIY untuk selalu mencegah segala upaya yang menyimpang yang mungkin akan terjadi, pengawasan itu bisa memberikan salah satu sistem jera untuk memberikan sanksi atas segala penyimpangan yang sudah terjadi. Untuk itu sangat diperlukan adanya penetapan Upah Minimum sebagai upaya melindugi para pekerja/buruh sehingga upah yang diterimanya dapat menjamin kesejahteraan bagi dirinya maupun keluarganya dan para 
pekerja/buruh tidak diperlakukan semena-mena oleh pengusaha yang mempunyai kewenangan dan kekuasaan dibalik kelemahan-kelemahan yang dimiliki oleh para pekerja/buruh. Disisi lain perlu diperhitungkan dampak dari penetapan Upah Minimum terhadap peningkatan dan pertumbuhan perusahaan. Penetapan Upah Minimum yang hanya melihat dari sudut kepentingan pekerja/buruh sangat tidak menguntungkan terhadap kelangsungan hidup perusahaan. Hal ini dikarenakan adanya dua sisi yang perlu mendapatkan perlindungan secara adil. Pekerja/buruh sangat membutuhkan upah yang memadai demi pemenuhan kebutuhan hidupnya beserta keluarga namun demikian perusahaan perlu mendapatkan jaminan dalam peningkatan dan pengembangan usahanya.

\section{Teori Serikat Pekerja}

Undang-undang Nomor 13 Tahun 2003 tentang Ketenagakerjaan menjelaskan serikat pekerja/buruh adalah organisasi yang dibentuk dari, oleh, dan untuk pekerja/buruh baik di perusahaan maupun diluar perusahaan, yang bersifat bebas, terbuka, mandiri, demokratis, dan bertanggung jawab guna memperjuangkan, membela serta melindungi hak dan kepentingan pekerja/buruh dan keluarganya (UU No 13 Tahun 2003 tentang Ketenagakerjaan pasal 1 angka 17). Kehadiran organisasi pekerja dimaksudkan untuk memperjuangkan hak dan kepentingan pekerja, sehingga tidak diperlakukan sewenang-wenang oleh pihak pengusaha. Keberhasilan dimaksud sangat tergantung dari kesadaran para pekerja untuk mengorganisasikan dirinya, semakin baik organisasi itu, maka akan semakin kuat. Sebaliknya semakin lemah, maka semakin tidak berdaya dalam melakukan tugasnya. Karena itulah kaum pekerja/buruh di Indonesia harus menghimpun dirinya dalam suatu wadah atau organisasi (Husni, 2007: 3738). Keberadaan serikat pekerja/buruh sangat penting dalam rangka memperjuangkan, membela dan melindungi hak dan kepentingan pekerja/buruh serta melakukan upaya-upaya untuk meningkatkan kesejahteraan pekerja/buruh dan keluarganya. Undang-undang Nomor 21 Tahun 2000 tentang serikat pekerja/buruh memuat beberapa prinsip dasar yaitu:

1. Serikat buruh, dibentuk atas kehendak bebas/pekerja tanpa tekanan atau campur tangan pengusaha, pemerintah dan pihak manapun.

2. Jaminan bahawa setiap pekerja/buruh berhak membentuk dan menjadi anggota serikat pekerja/buruh.

3. Basis utama serikat pekerja/buruh ada di tingkat perusahaan, serikat buruh yang ada dapat mengembangkan diri dalam Federasi Serikat Pekerja/Buruh. Demikian halnya dengan Federasi Serikat Pekerja/Buruh dapat menggabungkan diri dalam Konfederasi Serikat Pekerja/Buruh.

4. Serikat pekerja/buruh dapat dibentuk berdasarkan sektor usaha, jenis pekerjaan, atau bentuk lain sesuai dengan kehendak pekerja/buruh.

5. Serikat pekerja/buruh, federasi dan konfederasi serikat pekerja/buruh yang telah terbentuk memberitahukan secara tertulis kepada kantor DISNAKER setempat untuk dicatat.

6. Siapapun dilarang menghalang-halangi atau memaksa pekerja/buruh untuk membentuk atau tidak membentuk, menjadi atau tidak menjadi anggota dan atau menjalankan atau tidak menjalankan kegiatan serikat pekerja/buruh.

Tugas yang diemban oleh serikat pekerja/buruh menjadi semakin berat seiring dengan kebebasan pekerja/buruh untuk mengorganisasikan dirinya, yakni tidak saja memperjuangkan hak-hak normatif pekerja/buruh tetapi juga memberikan perlindungan, pembelaan, dan mengupayakan peningkatan kesejahteraannya (Husni, 2007: 42-44).

\section{METODE PENELITIAN}

Penelitian ini mengambil di Dinas Tenaga Kerja dan Transmigrasi Provinsi DIY sebagai lokasi observasi dan penelitian. Subjek dalam penelitian ini merupakan pejabat pemerintah 
pada Dinas Ketenagakerjaan dan Transmigrasi Provinsi, pekerja, dan serikat pekerja yang berada pada lokasi DIY. Data primer diperoleh secara langsung melalui observasi dan wawancara di lapangan, data sekunder yang dijadikan sebagai data penguat dan pendukung dalam penelitian ini berasal dari Dinas Tenaga Kerja dan Transmigrasi, Badan Pusat Statistik (BPS) dan data dari pemerintah DIY. Teknik analisis data yang digunakan untuk membahas hasil penelitian ini menggunakan teknik analisis kualitatif. Adapun siklus teknik analisis Kelayakan Hidup Layak dalam mendapatkan upah yang layak bagi pekerja/buruh dalam peningkatan kesejahteraan sebagai berikut: Pengumpulan data, Klasifikasi data, Mengolah data, Analisis data dan Kesimpulan.

\section{HASIL PENELITIAN}

Keberhasilan untuk memenuhi tujuan pencapaian Upah minimum Provinsi yang layak tidak lepas dari dukungan berbagai Organisasi serikat Buruh atau Pekerja dalam melakukan kegiatan untuk selalu mengawal bagi kemajuan pengupahan di setiap tahunnya, sehingga Serikat Buruh terus memperhatikan nasib para pekerja/buruh untuk mendapatkan upah yang layak untuk setiap bidang pekerjaannya dan menjamin hak-hak dasar pekerja atau buruh untuk bekerja dan memenuhi kebutuhan hidup keluarga secara layak menuju tercapainya kesejahteraan hidup yang diharapkan. Adanya serikat buruh bertujuan untuk memenuhi tuntutan Kelayakan Hidup Layak dan kebutuhan setiap bulannya, sasaran adanya serikat Buruh adalah : mengawal dan menjamin kelayakan pengupahan bagi para pekerja untuk selalu mendapatkan upah yang layak di setiap tahunnya yang diberikan kepada para pekerja.

Dalam upaya peningkatan Kelayakan Hidup Layak bagi para pekerja Konfederasi serikat Pekerja Seluruh Indonesia DIY memiliki strategi yang terbentuk dalam pengawalan dan perlawanan yang dituangkan dalam peraturan surat keterangan Gubernur, berkaitan dengan rendahnya pengupahan yang diterima oleh pekerja atau buruh di provinsi DIY yang tidak sesuai dengan terus naiknya biaya hidup yang harus dikeluarkan untuk setiap harinya dalam memenuhi kebutuhannya. Segala problematika dalam sektor pengupahan coba diurai dari waktu ke waktu, salah satunya ialah melalui Organisasi Serikat Buruh yang terus didorong untuk selalu mengeluarkan pendapat dan sarannya kepada pihak Pemerintah Provinsi DIY supaya selalu memperhatikan kesejahteraan bagi para pekerja atau buruh hal ini tentu saja memiliki dasar berfikir serta pertanggungjawaban yang bagus dalam pelaksanaannya.

A) Kompensasi Besaran UMP dan KHL Provinsi DIY

Setiap tahun Konfederasi Serikat Pekerja Seluruh Indonesia Provinsi DIY mengalami dinamika yang berbeda-beda, hal tersebut mempengaruhi program kegiatan setiap tahunnya. Dalam proses menganalisis untuk menaikan Kelayakan Hidup Layak setiap tahunnya penulis membandingkan dari hasil survey Kelayakan Hidup Layak dalam 2 tahun kebelakang, yakni antara tahun 2018 dan 2019. Berikut tabel hasil survey Kelayakan Hidup Layak pada 2 tahun tersebut :

$1 \quad$ Beras Sedang Sedang $10 \mathrm{~kg}$

2 Sumber Protein :
a. Daging Sedang $0.75 \mathrm{~kg}$
b. Ikan Segar Baik $1.2 \mathrm{~kg}$
c. Telur Ayam Telur ayam ras $1 \mathrm{~kg}$
3 Kacang-kacangan : tempe/tahu Baik $4.5 \mathrm{~kg}$
4 Susu bubuk Sedang0.9 kg
5 Gula pasir Sedang $3 \mathrm{~kg}$
6 Minyak goreng Curah $2 \mathrm{~kg}$
7 Sayuran Baik $7.2 \mathrm{~kg}$
8 Buah-buahan (setara pisang/pepaya) Baik $7.5 \mathrm{~kg}$
$9 \quad$ Karbohidrat lain (setara tepung terigu) Sedang $3 \mathrm{~kg}$ 
10 Teh atau Kopi Celup/Sachet 2 Dus isi $25=75 \mathrm{gr}$

11 Bumbu-bumbuan Nilai $1 \mathrm{~s} / \mathrm{d} 10 \quad 15 \%$

12 Celana panjang/ Rok/Pakaian muslim Katun/sedang 6/12 potong

13 Celana pendek Katun/sedang 2/12 potong

14 Ikat Pinggang Kulit sintetis, polos, tidak branded $1 / 12$ buah

15 Kemeja lengan pendek/blouse Setara katun 6/12 potong

16 Kaos oblong/ $\mathrm{BH} \quad$ Sedang $6 / 12$ potong

17 Celana dalam Sedang6/12 potong

18 Sarung/kain panjang Sedang $1 / 12$ helai

19 Sepatu Kulit sintetis 2/12 pasang

20 Kaos Kaki Katun, Polyester, Polos, Sedang 4/12 pasang

21 Perlengkapan pembersih sepatu
a. Semir sepatu
Sedang $6 / 12$ buah
b. Sikat sepatu Sedang $1 / 12$ buah

Sandal jepit Karet 2/12 pasang

23 Handuk mandi $100 \mathrm{~cm} \times 60 \mathrm{~cm}$

$2 / 12$ potong

24 Perlengkapan ibadah
a. Sajadah Sedang $1 / 12$ potong
b. Mukena Sedang $1 / 12$ potong
c. Peci,dll Sedang 1/12 potong

25 Sewa kamar dapat menampung jenis KHL lainnya 1 bulan

26 Dipan/tempat tidur No.3, polos 1/48 buah

27 Perlengkapan tidur
a. Kasur busa Busa 1/48 buah
b. Bantal busa Busa 2/36 buah

Sprei dan sarung bantal

Katun $2 / 12$ set

29 Meja dan kursi 1 meja/4 kursi1/48 set

30 Lemari pakaian Kayu sedang 1/48 buah

31 Sapu Ijuk sedang 2/12 buah

32 Perlengkapan makan
a. Piring makan
Polos 3/12 buah
b. Gelas minum
Polos 3/12 buah
c. Sendok garpu
Sedang $3 / 12$ pasang

Ceret aluminium

Ukuran $25 \mathrm{~cm} 1 / 24$ buah

Wajan aluminium

Ukuran $32 \mathrm{~cm} 1 / 24$ buah

Panci aluminium Ukuran $32 \mathrm{~cm} 2 / 12$ buah

36 Sendok masak Alumunium 1/12 buah

37 Rice Cooker ukuran 1/2 liter 350 watt

$1 / 48$ buah

38 Kompor dan perlengkapannya

$\begin{array}{llll} & \text { a. Kompor 1 tungku SNI } & 1 / 24 \text { buah } \\ & \text { b. Selang dan regulator } & \text { SNI } \quad 10 \text { liter } \\ & \text { c. Tabung Gas } 3 \mathrm{~kg} \quad \text { Pertamina } & 1 / 60 \text { buah } \\ 39 & \text { Gas Elpiji masing-masing } 3 \mathrm{~kg} & 2 \text { tabung } \\ 40 & \text { Ember plastik Isi } 20 \text { liter } & 2 / 12 \text { buah } \\ 41 & \text { Gayung plastik } \quad \text { Sedang } 1 / 12 \text { buah } \\ 42 & \text { Listrik 900 watt } \quad 1 \text { bulan } \\ 43 & \text { Bola lampu hemat energi } 14 \text { watt3/12 buah } \\ 44 & \text { Air Bersih Standar PAM 2 meter kubik } \\ 45 & \text { Sabun cuci pakaian Cream/deterjen } 1.5 \mathrm{~kg} \\ 46 & \text { Sabun cuci piring (colek) } 500 \text { gr } 1 \text { buah }\end{array}$


48 Rak portable plastik Sedang $1 / 24$ buah

49 Pisau dapur Sedang $1 / 36$ buah

50 Cermin $30 \times 50 \mathrm{~cm} \quad 1 / 36$ buah

51 Bacaan/radio Tabloid/4 band 4 buah/ (1/48)

52 Ballpoint/pensil Sedang $6 / 12$ buah

JUMLAH

53 Sarana Kesehatan

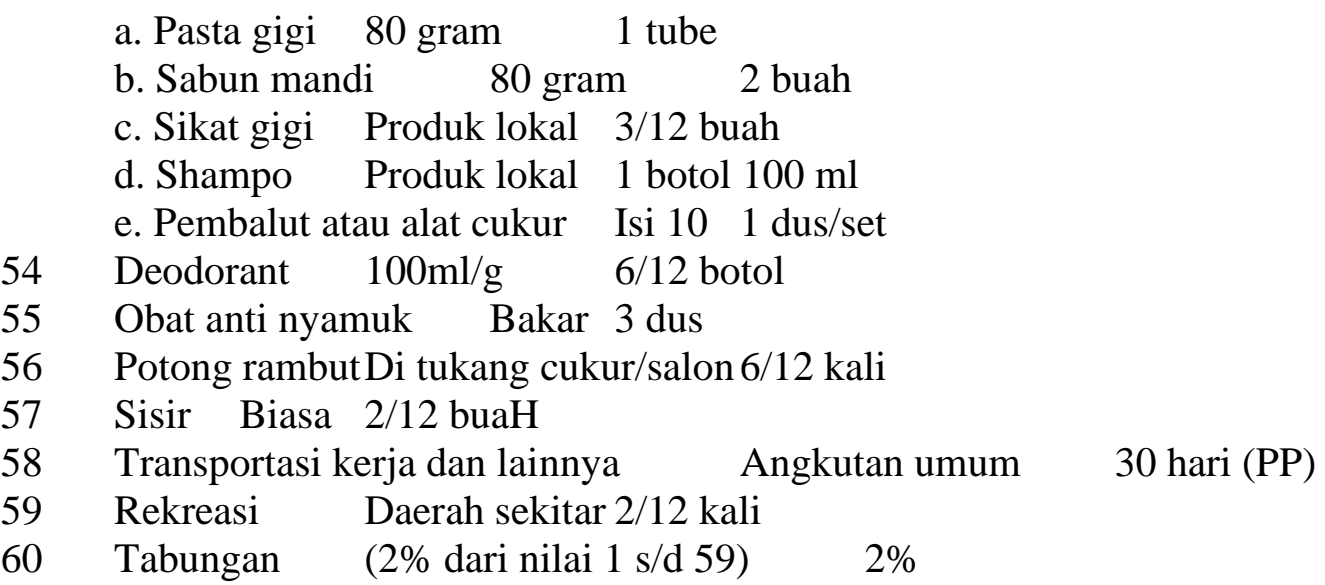

Sumber : Peraturan Menteri ketenagakerjaan No 21 tahun 2016 tentang Kebutuhan Hidup layak.

Berdasarkan regulasi ketenagakerjaan di Indonesia, kebutuhan hidup layak, menjadi dasar penetapan Upah Minimum. Hal ini diukur dari standar kebutuhan pekerja lajang untuk dapat hidup layak secara fisik dalam bertahan hidup untuk waktu satu bulan. Nilai ini masih menjadikan perdebatan dikarenakan antara pengusaha dan serikat pekerja tidak sejalan dalam pendapatnya, dalam Konfederasi Serikat Pekerja Seluruh Indonesia, komponen KHL seharusnya terdiri dari 78 jenis kebutuhan, yang artinya nilai KHL harus lebih besar, dengan demikian Upah minimum yang didapatkan juga lebih tinggi yaitu 20\% hingga 25\%. Tetapi dalam kenyataannya tetap saja masih menggunakan regulasi yang lama yaitu masih dengan menggunakan 60 komponen Dengan hal ini KSPSI DIY melakukan survei di lima pasar tradisional yang berada di kabupaten kota di Provinsi DIY, diantaranya pasar Kranggan Yogyakarta, pasar Godean Sleman, pasar Niten Bantul, pasar Wates Kulon Progo dan pasar Wonosari Gunung Kidul. Kebutuhan hidup pekerja dalam setiap tahunnya mengalami peningkatan untuk mencukupi kehidupannya dalam kurun waktu setiap bulan, kenaikan itu dipengaruhi dengan kenaikan harga kebutuhan hidup bagi pekerja di setiap tahunnya, selain dipengaruhi dengan kenaikan harga kebutuhan hidup terdapat peraturan pemerintah yang selalu menekan untuk memberikan upah yang cukup layak bagi para pekerja di DIY. Dengan hal ini seharusnya pihak DISNAKERTRANS dapat melihat kembali usulan dari pihak KSPSI DIY untuk lebih memahami kebutuhan dan kenaikan bahan baku kebutuhan pekerja/buruh, dan pihak DPD KSPSI DIY menemukan hasil besaran upah minimum provinsi dengan besaran sebagai berikut : 
Table .4 Hasil Besaran Upah Minimum Provinsi

\begin{tabular}{lll}
\hline No & Pasar Tradisional Kab. & Data Survey KHL 2019 \\
\hline 1. & Kota Jogja & Rp. 2.797 .313 \\
\hline 2. & Sleman & Rp. 2.695.997 \\
\hline 3. & Bantul & Rp. 2.559.011 \\
\hline 4. & Kulon Progo & Rp. 2.507.550 \\
\hline 5. & Gunung Kidul & Rp. 2.501.142 \\
\hline 6. & Rata-rata & Rp. 2.612.203 \\
\hline \multicolumn{2}{c}{ Sumber: Data survei Kelayakan Hidup layak DPD KSPSI DIY tahun 2019 }
\end{tabular}

Tabel 4. menunjukkan bahwa dari hasil survei DPD KSPSI DIY ditemukan besaran upah yang ideal untuk daerah provinsi Yogyakarta untuk mencukupi kebutuhan pekerja/buruh dalam kurun waktu setiap bulannya, DPD KSPSI mengeluarkan data tersebut tidaklah sembarangan, karena DPD KSPSI selalu rutin melakukan survei KHL setiap tahunnya untuk mengetahui kenaikan harga kebutuhan yang dibutuhkan sebagai pedoman untuk menyikapi keputusan dari pihak DISNAKERTRANS yang terus disahkan oleh Gubernur DIY. Pada kenyataannya komponen KHL masih sama dengan tahun sebelumnya yang mengacu pada Peraturan Pemerintah Tenaga kerja dan Transmigrasi NO.13 Tahun 2012 Tentang komponen KHL dan pelaksanaannya tahapan pencapaian KHL, pada peraturan menteri tersebut terdapat 7 komponen KHL, yaitu makanan dan minuman, sandang, perumahan, Pendidikan, kesehatan, transportasi serta rekreasi dan tabungan.

Tabel .5 Kenaikan UMP DIY Pada Tahun 2019

\begin{tabular}{|c|c|c|c|}
\hline No & Upah minimum Provinsi & UMK & Prosentase \\
\hline 1. & Kota Yogyakarta & Rp. 1.846 .400 & $8.03 \%$ \\
\hline 2. & Kab. Sleman & Rp. 1.701 .000 & $8,03 \%$ \\
\hline 3. & Kab. Bantul & Rp. 1.649 .800 & $8,03 \%$ \\
\hline 4. & Kab. Kulonprogo & Rp. 1.613.200 & $8,03 \%$ \\
\hline 5. & Kab. Gunung Kidul & Rp. 1.705 .000 & $8,03 \%$ \\
\hline
\end{tabular}

Tabel 5. menjelaskan bahwa kenaikan UMP DIY pada tahun 2019 hanya mampu memberikan kenaikan yang tidak terlalu tinggi yaitu hanya terdapat kenaikan upah sebesar $8,03 \%$ dengan prosentase besaran upah tersebut belumlah layak untuk mencukupi kebutuhan pekerja/buruh dalam memenuhi kebutuhan pada setiap bulannya karena harga kebutuhan hidup setiap tahunnya naik terlalu besar dan kebutuhan untuk menunjang keperluan sehari-harinya. Dalam menetapkan besaran upah minimum provinsi, Dewan Pengupahan Provinsi yang terdiri dari pemerintah, serikat pekerja, dan pemberi kerja, bersama-sama melakukan survei setiap tahun. Penetapan besaran upah melalui survei sangat penting untuk dilakukan untuk memperoleh batasan upah minimal yang wajib disepakati oleh para pihak (tenaga kerja dan pemberi kerja). Saat ini, hasil survei menunjukkan harga komponen pasar sudah naik semua, sehingga upah perlu disesuaikan. Meskipun demikian, salah satu kendala yang dihadapi dalam melakukan survei adalah dalam hal pendanaan karena sampai saat ini belum ada dana yang dialokasikan khusus untuk survei.

Untuk menyiasati kendala pendanaan tersebut sering dilakukan sampling dalam survei, yaitu pengambilan responden secara acak. Hasil survei yang dilakukan oleh Dewan Pengupahan ditujukan untuk menentukan besaran UMP. Kemudian berdasarkan besaran UMP tersebut, Dewan Pengupahan Provinsi mengusulkan kepada gubernur untuk ditetapkan sebagai UMP. Dengan hal tersebut akan menimbulkan ketimpangan dalam hal pengupahan bagi para pekerja untuk memenuhi kebutuhan setiap bulannya. 


\section{KESIMPULAN DAN SARAN}

Mengenai analisis Kelayakan Upah Minimum Provinsi DIY dalam memenuhi kebutuhan hidup layak tahun 2019, yang mengemukakan bahwa proses perumusan hingga penetapan upah minimum di Provinsi Daerah Istimewa Yogyakarta adalah masih belum bisa memenuhi kebutuhan hidup layak bagi para pekerja, dalam tahapan pengupahan, pertama kali dilakukan oleh Dewan Pengupahan, yang dilakukan survei di lima pasar tradisional yang berbeda untuk mengetahui harga kenaikan bahan dasar kebutuhan sehari-hari pada tiap tahunnya, hasil yang didapatkan dalam survei pasar tradisional dijadikan pedoman yang kemudian dijadikan dalam agenda pembahasan di Dewan Pengupahan dengan berdasarkan musyawarah maupun perundingan kedua belah pihak sehingga mendapatkan hasil kesepakatan bersama. Hasil dari kesepakatan tersebut hanya digunakan sebagai landasan untuk pengusulan saja bukan hasil sebagai penentunya, wewenang sebagai hasil penentuan besarnya upah minimum ada pada keputusan tingkat Gubernur.

Berdasarkan dari hasil penelitian dan pembahasan terdapat analisis dan faktor-faktor yang akan menjadikan pertimbangan utama dalam penetapan Upah Minimum Provinsi DIY pada tahun 2018-2019 maka dapat disimpulkan sebagai berikut: Upah yang sesuai dengan ketetapan merupakan upah untuk selalu memenuhi kebutuhan hidup layak pekerja/buruh dan keluarga sehingga kebutuhan pekerja/buruh dapat tercukupi dan hidup sejahtera. Faktor yang menjadikan pertimbangan untuk menentukan penetapan upah minimum provinsi adalah kebutuhan hidup layak (KHL) dengan selalu memperhatikan dari segi faktor inflasi dan pertumbuhan ekonomi maka dapat meningkatkan perhitungan upah minimum provinsi pada jangka tahun berikutnya.

Indikator kebijakan, indikator kelayakan dan indikator keadilan kedua belah pihak masih sama-sama belum menerima hasil kepuasan dari kesepakatan bersama yang menjadi kepentingan mereka, pada pihak pengusaha menekankan bahwa kenaikan upah tidak dibarengi dengan tingkat produktivitas pekerjanya sehingga pihak perusahaan merasa keberatan memberikan upah minimum tersebut. Sedangkan dari pihak pekerja juga menekankan bahwa upah minimum yang selama ini diberikan tidak memenuhi standar kebutuhan hidup layak, karena penilaian pemberian upah hanya berdasarkan pekerja lajang saja sehingga bagi pihak pekerja yang sudah berkeluarga, merasa bahwa upah tersebut tidaklah cukup untuk memenuhi kebutuhan keluarganya, sehingga mendorong dari pihak pemerintah untuk memahami dan mencermati akan hal tersebut untuk mendapatkan kelayakan upah yang mencukupi standar kebutuhannya.

Berdasarkan hasil penelitian pada upaya mengawasi Kelayakan Hidup Layak bagi para pekerja di Daerah Istimewa Yogyakarta pada Konfederasi Serikat Pekerja Seluruh Indonesia pada tahun 2019, penulis memberikan saran sebagai berikut: sistem pengupahan nasional haruslah diberlakukan agar penetapan upah berada di atas kebutuhan hidup minimum dan penetapan sistem pengupahan nasional harus mempertimbangkan faktor-faktor seperti KHL, produktivitas, pertumbuhan ekonomi, kondisi pasar kerja, kemampuan bayar perusahaan. Tentunya, disesuaikan dengan kondisi dan kemampuan masing-masing daerah. Penetapan upah melalui sistem pengupahan nasional juga diarahkan untuk meningkatkan kesejahteraan tenaga kerja, meningkatkan produktivitas, serta mengupayakan pemerataan pendapatan dalam rangka menciptakan keadilan sosial, dan dapat mencakup beberapa tujuan standar kesejahteraan pekerja/buruh yaitu: Untuk menciptakan standar upah yang layak bagi pekerja hendaknya pemerintah dapat mengubah peraturan yang menyebutkan bahwa "KHL adalah standar kebutuhan yang harus dipenuhi oleh pekerja lajang”, sehingga pekerja yang tergolong sudah berkeluarga mendapatkan jaminan kehidupan yang layak untuk memenuhi kebutuhannya anggota keluarganya. Meningkatnya nilai upah sangatlah berhubungan dengan perubahan pada besaran nilai kebutuhan hidup layak (KHL) masyarakat pada wilayah atau daerah satu dengan daerah lainnya, maka faktor dan harga yang termasuk dalam indikator 
perhitungan kebutuhan hidup layak secara berkala harus mengalami pembaharuan dalam kurun waktu setiap tahunnya. Diharapkan untuk semua organisasi masyarakat ataupun serikat pekerja yang terkait dengan penetapan upah minimum terus melakukan pengawasan terhadap harga yang termasuk dalam kebutuhan hidup layak untuk menjaga kestabilan harga sehingga upah minimum dapat terjaga kestabilannya dan masyarakat menjadi sejahtera. Agar pelaksanaan upah minimum berjalan dengan baik maka perlu diadakannya sosialisasi yang ditujukan kepada pengusaha, pekerja/buruh, serikat pekerja/serikat buruh, pemerintah, dewan pengupahan tentang upah minimum serta yang berkaitan dengan upah minimum. Peneliti berharap akan ada penelitian lanjutan dengan cakupan yang lebih luas dan mendalam terkait hal-hal yang menjadi pertimbangan utama dalam penetapan upah minimum provinsi (UMP) di Indonesia.

\section{DAFTAR PUSTAKA}

Djumiadi,F.X,(2008). Perjanjian Kerja Edisi Revisi, SinarGrafika, Jakarta.

Sugiyono, (2015). Metode Penelitian Kuantitatif, Kualitatif dan R\&D.

widayanti (2018) Tinjauan Peraturan Pemerintah Republik Indonesia NO.78 Tahun 2015 tentang pengupahan dalam Mencapai Kebutuhan Hidup Layak (KHL) di kota Semarang.

Ahsanwani. (2018) Peran Serikat Pekerja Berdasarkan Undang-Undang no.13 Tahun 2003 tentang ketenagakerjaan (studi kasus pembelaan hak-hak buruh oleh KSPSI di Kabupaten Tangerang.

Kausar Oktiandy, Mujibussalim. (2018) Peran Konfederasi Serikat Pekerja Indonesia (KSPI) Aceh dalam Memperjuangkan Politik Pengupahan di Aceh

Suhartoyo. (2018) Penguatan Organisasi Buruh / Pekerja Sebagai Sarana Perlindungan Buruh.

Hery Styawan, Mochamad Arif afandi. (2017) Strategi Perjuangan Serikat Buruh Dalam Tuntutan Kenaikan Upah Kabupaten Jombang.

Sonhaji. (2019) Organisasi Serikat Pekerja Terhadap Kesejahteraan Pekerja atau Buruh di PT.Apac Inti Corpora.

Ndaru sri Arthawati. (2018) Peran SErikat Pekerja dalam Mendorong Produktivitas Dan Peningkatan Kesejahteraan Para Pekerja Pada PT Nippon Shokubai Indonesia-Cilegon

Richard Ghufron, Hamidah Nyatai Utami. (2018) Resistensi Buruh Terhadao Peraturan Pemerintah No 78 Tahun 2015 Tentang Pengupahan (studi kasus pada Solidaritas Perjuangan Buruh Indonesia (SPBI) Malang)

Zulkarnain Ibrahim. (2018) Eksistensi Serikat Pekerja/Buruh Dalam Mensejahterakan Pekerja.

Suhartoyo. (2018) Penguatan Organisasi Buruh/pekerja Sebagai Saran perlindungan buruh

Undang-Undang Nomor 13 Tahun 2003 Tentang Ketenagakerjaan.

Peraturan Pemerintah Nomor 78 Tahun 2015 tentang Pengupahan.

Undang-Undang Nomor 21 Tahun 2000. 